\title{
SIDE EFFECTS OF USING OF SOME FOLIAR FERTILIZERS ON BIOLOGY OF COTTON LEAF WORM, SPODOPTERA LITTORALIS (BOISD.) UNDER LABORATORY CONDITIONS
}

\author{
MAKKAR, A.W., MANSOUR, E. S. AND AML, A. ABD-ALLAH \\ Plant Protection Research Institute, ARC, Dokki, Giza, Egypt.
}

(Manuscript received 21 September 2014)

\begin{abstract}
An experiment was conducted at Qaha Research Station, Qalubia governorate, during 2013 cotton season, to study the effects of four foliar fertilizers on biological aspects of cotton leaf worm, Spodoptera littoralis (Boisd.), for three successive generations. (Canada magic, Canada sal, Canada foliar and Canada amino) were sprayed on cotton leaves in field and introduced to the newly hatched larvae. The obtained results revealed that the larval stages suffered greatest mortality followed by the pre-pupal stage, the pupal stage and lastly the moths for the four compounds. The highest mean percentage mortality of overall immature stages within the three generations $(98.8,98.2,98.0$ and $96.3 \%$ ) was (Canada sal, Canada amino, Canada magic and Canada foliar), respectively. Analysis of variance between the mean larval duration and Percentage pupation for the remaining larvae and pupae of the three generations, showed significant differences between treatments and control (L.S.D $=2.33 \& 6.3$ ), respectively. Moreover, all larvae fed on treated leaves gave the least percentage of adults' emergence and a few malformations, also, no eggs were laid by the resulting females in the three generations. Data demonstrated that the larval and pupal weights recorded insignificant differences between treated and untreated.

Key words: Spodoptera littoralis, foliar fertilizers
\end{abstract}

\section{INTRODUCTION}

The cotton leafworm, Spodoptera littoralis (Boisd.) is a major pest of various vegetable and field crops in Egypt, but it prefers some of its hosts such as Cotton, Gossypium barbadense L., rather than others. Also, cotton growers in Egypt have experienced severe economic losses from cotton pests due to reduced yield. Low lint quality and increased costs of insecticides (Amin and Gergis2006). Several authors Badr, 1967, El-Saadany et al., 1994) contributed to the biology of Spodoptera littoralis and the effect of different host plants on its development and reproduction capacity. In the recent years, some investigators described new approach as a good tool in pest management system such as foliar nutrient spray to produce a profitable cotton crop and minimized the outbreak of insect pests (Ying- Zhi Chen, et al., 2004, El-Naggar and Tawfeek 2012). Foliar spray can, also, correct deficiencies of certain required nutrients in large amounts (Macro- elements) and for required in trace amounts 
(Micro- elements) (Mesbah et al., 2000 and El- Naggar, 2009) indicated farming practices that cause nutrition in balance can lower pest resistance.( Meyer, 2000 )proposed that soil nutrient availability not only affects the amount of damage that plants receive from herbivores but also the ability of plants to recover from herbivores. Ramesh, et al., 2005 conducted that organic crops have been shown to be more tolerant as well as resistant to insect attacks. Saad and Nabil 2012 were studied the effects of some foliar fertilizers on the biology of silkworm, Bombyx mori L. In this study, the authors investigated the possibilities of using four compounds as foliar fertilizers to determine the new beneficial effects on larval and pupal mortality and larval, pupal weights, finally, the effect of these compounds on some biological aspects of cotton leaf worm, Spodoptera littoralis.

\section{MATERIALS AND METHODS}

The present experiment was conducted at Qaha Agricultural Research Station, Qualubia Governorate, during 2013 cotton season. Five experimental areas (each $175 \mathrm{~m}^{2}$ ) every area(plot) was divided into 4 replicates and cultivated with cotton variety Giza 86 on March $24^{\text {th }}$ ) each plot was separate from the adjacent one by a half meter belt (barrier) to minimize the interference of spray drift from one treatment to another. Four plots were sprayed four times, each with one of the following materials, Canada magic, Canada sal, Canada foliar and Canada amino. The fifth plot was sprayed with fresh water as control. These compounds are produced by Egyptian Canadian for Humate Technology and Agricultural consultancy.

\section{Materials used:}

- Canada magic : The main components are:

Nitrogen 12\% - Phosphorous 12\% - Potassium 12\% - Calcium 1\% Magnesium 0.14\% -Iron 1.5\% - Manganese 0.6\% - Zinc 0.14\% -Copper 0.06\% -Boron $0.13 \%$-Molybdenum $0.06 \%$-amino acids 10\%- Fulvic acid 3\% - Humic acid $10 \%$ and growth catalyst $10 \%$.

- Canada sal : The main components are:

Calcium polyhydroxy carboxyl $20 \%$ - active organic matters $25 \%$-Total organic maters $75 \%$.

- Canada foliar: The main components are: Nitrogen 5\% -Phosphorous 7\% Potassium 6\% -Iron 1\% -Zinc 0.2\% - Manganese 0.3\% -Copper $0.1 \%$ - Sulfur $4 \%$ - Boron $0.5 \%$ - Molybdenum $0.01 \%$ - amino acid $5 \%$-active fulvic acid $15 \%$.

- Canada amino: The main components are: 
- Nitrogen 5\% -Phosphorous 3\% - Potassium 4\% -Iron 1.5\% - Zinc 1.1\% Manganese $1.1 \%$ - Humic acid $10 \%$-amino acids $10 \%$ - and active fulvic acid $2.5 \%$.

\section{- Fresh water as control.}

\section{Test insect:}

Culture of cotton leaf worm, Spodoptera littoralis (Boisd.) was obtained from batches of egg collected from neighboring fields. Larvae were reared for one generation on the cotton leaves under laboratory conditions. Newly hatched larvae from the next generation were used for test. A mean temperature of $27 \pm 2{ }^{\circ} \mathrm{C}$ and average R.H. of $70 \pm 5 \%$ were recorded during the course of the present study.

\section{Semi field experiment:}

From the five treated areas, cotton leaves were collected at zero time and until the end of 15 days. These leaves were transferred directly to the laboratory for feeding the larval instars.

\section{Larval development:}

About 200 newly emerged larvae were transferred and divided into four replicates each in glass jar and provided with treated cotton leaves. The number of dead larvae was recorded daily. The duration of the larval stage was determined at the end of the $6^{\text {th }}$ larval instar.

\section{Pre- pupal and pupal development:}

The number of dead pre- pupal and pupal was recorded daily and the duration of the pre pupal and pupal stage was determined.

\section{Adult development}

The newly emerged moths were confined in a glass jars (Ca. $250 \mathrm{ml}$ ). The number of dead moths was recorded daily, also, adult was examined for deformities.

\section{Egg development:}

Eggs were obtained from each generation reared in the laboratory. Egg laid on Tafla (Nerium deander) was distributed in small petri dishes. The total eggs were incubated at laboratory temperature. Eggs were observed daily until hatching occurred.

\section{Statistical analysis:}

Data obtained were subjected to the analysis of variance and the mean was compared using the $F$ value, L.S.D test at $P<0.05$.

\section{Date of treatments:}

First spray $20 / 5 / 2013$

Second spray $4 / 6 / 2013$

Third spray $18 / 6 / 2013$

Fourth spray $9 / 7 / 2013$ 


\section{The rate of recommended concentrations were:}

- Canada magic: $100 \mathrm{~g} / 100 \mathrm{~L}$ water per Feddan.

- Canada sal. : 50 cc / 100 L water per Feddan.

- Canada foliar: $150 \mathrm{cc} / 100 \mathrm{~L}$ water per Feddan.

- Canada amino: 250 CC/ 100 L water per Feddan.

\section{RESULTS AND DISCUSSION}

\section{Total mortality of cotton leaf worm, Spodoptera littoralis (Boisd.) on different treatments:}

- Larval mortality:

The percentage of mortality of $S$. litttoralis on different treatments is given in Table (1) and Fig. $(1,2,3)$ detected that the highest percentage of larval mortality were observed for all treatments as foliar fertilizers. But the highest percentage of larval mortality (95\%) were obtained when larvae fed on cotton leaves were sprayed with Canada magic in the second and third generations. Also, the same results occurred when larvae fed on cotton leaves were sprayed with Canada sal in the first generation. The remaining results of percentage mortality for the four 'compounds in the three generations ranged ( 83 to $95 \%$ ). On the contrary, the lowest percentage of larval mortality $(33,35$ and $25 \%$ ) occurred when larvae fed on cotton leaves were sprayed with fresh water (control) in the three generations, respectively. There were significant differences noticed between all treatments with four compounds when compared with the untreated cotton leaves (sprayed with fresh water), where, L. S. D. $=(5.45,6.47$ and 6.59$)$ in the three generations, respectively.

\section{- Pre- pupal and pupal mortality:}

The highest percentage of pre-pupal and pupal mortality (10 and $3 \%$ ) was observed in the first generation, when larvae fed on cotton leaves were sprayed with Canada magic and Canada sal, respectively. However, the lowest percentage (1\%) of pre-pupal mortality was observed with Canada sal. On the other hand, the remaining treatments gave no pupal mortality, also, the highest percentage (12.0 and 9.0\%) mortality was observed with Canda amino in both second and third generations, respectively. However, no pupal mortality was observed in the case of Canada magic in both second and third generations, respectively. From this investigation the obtained results revealed that the larval stages suffered from greatest mortality followed by pre-pupal stage then pupal stage and lastly the moths for all treatments as foliar fertilizers in the three generations. Finally, among the different littoralis within the three generations (98.8, 98.2, 92.6 and 96.3\%), respectively were on Canada sal, 
Canada amino, Canada magic and Canada foliar. However, the lowest mean mortality of immature stages (34.0\%) was on untreated (Table, 1). In the same trend Bahram Naser, et al., (2009) indicated that the percentage of mortality of $H$. armigera on different varieties of soybean, the highest percentage of larval, pre-pupal and pupal mortality was differed from verity to another. Moreover, in the case of untreated, the results in this study agreed with the findings by El-Saadany, et.al., (1994) in which the larvae fed on cotton leaves. Finally, the results obtained in this study revealed that the effect of these compounds may be related to some factors of the main components of the four testing compounds which conclude that humic acid, fulvic acid, active organic matters and some elements, which were associated with cotton plant, when were used as foliar fertilizers. Bryant, et al (1983) were pointed out to these factors, they reported that environmental factors are known to modulate primary and secondary chemical profiles of host plants.

\section{Larval duration (days) of remaining larvae:}

Treatments with foliar fertilizers (Canada magic, Canada sal, Canada foliar and Canada amino) have variable effects on development of larvae of cotton leaf worm, Spodoptera littoralis (Boisd.)

Data given in Table (2) clarified that duration of larval instars were affected by different treatments of the tested compounds. In the first generation the shortest mean duration ( $9.75 \pm 0.57$ and $10.08 \pm 0.50$ days) were recorded for larvae fed on cotton leaves were sprayed with Canada sal and Canada magic, respectively. The same results were recorded in the second generation, where the shortest mean duration (10.5 \pm 0.5 and $10.67 \pm 0.54$ days) was recorded for the same two treatments. On the contrary, the longest mean period for larval development $(17.0 \pm$ 0.91 days) resulted when larvae offered on cotton leaves were sprayed with fresh water (untreated) in the first generation. The same results were obtained in the third generation, where the mean duration ( $13.0 \pm 0.57$ days)., In the second generation, the longest mean period for larval development (13.3 \pm 0.62 days ) were obtained when larvae were fed on cotton leaves were sprayed with Canada amino. However, intermediate means duration was obtained for the remaining treatments in the three generations. Analysis of variance between the mean larval duration of the three generations showed that differences in the larval duration among treatments were significant (L.S.D= 2.33). Several investigators mentioned that, the shortest period of larval stage was obtained from larvae fed on leaves for different hosts. Badr (1967) found that sweet potato and castor oil tended to shorten the duration of the larval stage. Finally, these results agree med with those of Xia et al., (1997) who reported that increasing nitrogenous fertilizer rate to host plant reduced the larval period of $H$. armigera. Greiss 
and Petkove (2001) and Sannappa et al., (2003), they reported that the fertilization of mulberry tree with different methods gave the shortening of the larval stage of silkworm, Bombyx mori compared to the control, when larvae fed on mulberry leaves plantation with NPK and micronutrients. Also, Hwang et al., (2008) reported that larvae that fed on highly- nutritious foliage increased their growth rates and showed a shorter development period. On the same trend, Bansode and Purohit (2003). reported that, the development period of diamondback moth larvae was significantly influenced by levels of nitrogen supplied to food. Also, reported that diamondback moth larvae grew faster, when fed with increasing dose of N. fertilization to host plants. Also, Ying-Zhi Chen, et al, (2004) demonstrated that fertilization significantly changed the phytochemical content of B.olerracea var. capitata, these phytochemical changes were further associated with changes in the performance of cabbage white butterfly larvae.

\section{Pre-Pupal and pupal duration (day) of remaining pre-puae and Pupa:}

- Data illustrated in Table (2): showed that the Pre-Pual stage was not greatly affected with all treatments. The longest mean pre-Pupal duration was $(1.19 \pm$ 0.14 ) days for the larvae fed on untreated cotton leaves. However, the mean PrePupal duration was $(1.0 \pm 0.0)$ day obtained for larvae fed on the four treatments in the three generations. The above mentioned findings are in agreement with those found by El-Saadany et..al (1994), where the Pre-Pupal stage was (1.31 \pm 0.13 ) days when larvae fed on cotton leaves.

- Data in Table (2): cleared that, the shortest mean duration was (5.83 \pm 2.78 ) days for pupae obtained from larvae fed on cotton leaves were sprayed with Canada magic in the three generations.

However, the longest mean pupal duration was $(8.4 \pm 1.36)$ days resulted from larvae fed on untreated leaves. Analysis of variance showed that, no significant differences in pupal duration of the three generations between the four compounds (treatments) and untreated, where computed $(F)=0.55 \mathrm{df}=10$, Tabulated $(F)=3.48$. The same results obtained by Moufied et al., (1960), they found in the case of larvae fed on cotton and cowpea, the pupal duration reach 7.2 and 7.7 days respectively. The same results obtained by Carnevalli et al., (1990) who studied the effect of nitrogen on Spodoptera frugiperda and reported that pupal period was longest in treatment without nitrogen. However, Setamous et al., (1993) reported that pupal period of Sesamia calamistis was not affected by plant nitrogen. The same trend obtained by Bansode and Purohit (2003) who recorded that the pupal development period was not significantly affected by nitrogen levels. Obtained results agree with Ying- Zhi et al, (2004) they mentioned that fertilization significantly changed the phytochemical cotent of $B$. 
oleranced var. Capita. These phytochemical changes were associated with changes in the performance of cabbage white butter fly larvae. Performance (duration, growth rates and food processing efficiencies) of $4^{\text {th }}$ instar $P$. candida candida was varied significantly between fertilized and unfertilized host plant.

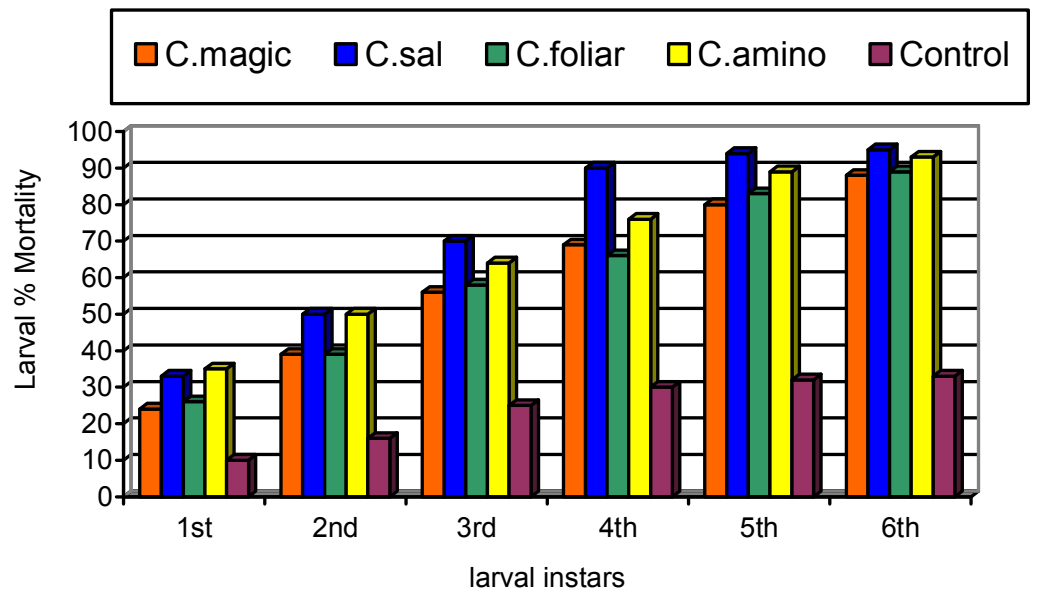

Fig. 1. A Cumulated percentage mortality within larval instars for the first generation.

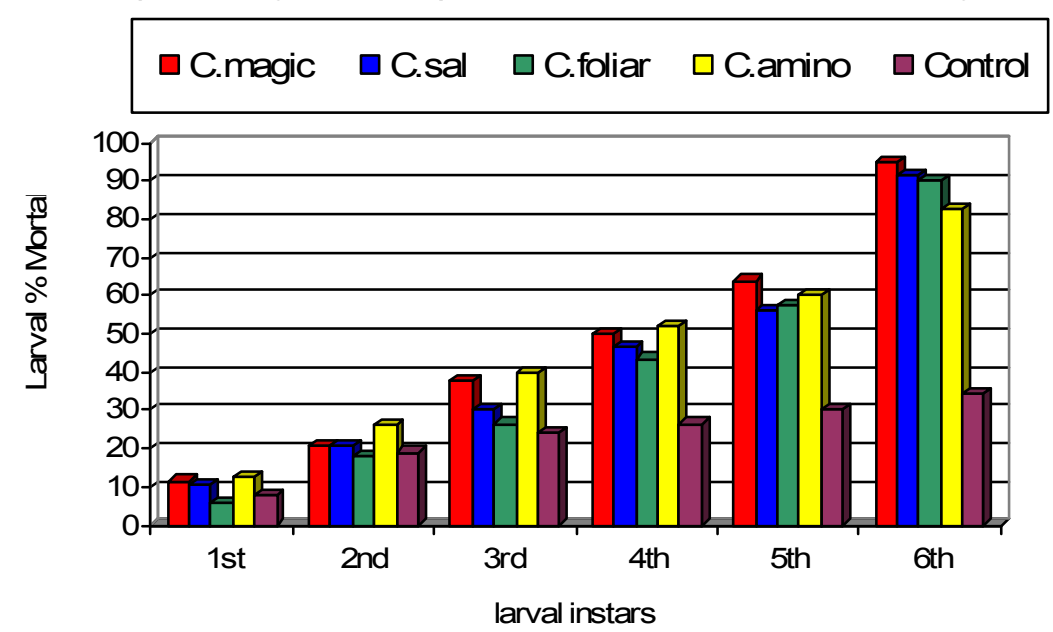

Fig. 2. Cumulated percentage mortality within larval instars for the second generation. 
Table 1. Total acumulated of larval mortality, pre-pupal and pupal mortality, normal and deformed moths mortality of cotton leafworm, S. littoralis on different treatments among three generations.

\begin{tabular}{|c|c|c|c|c|c|c|c|c|c|c|c|c|c|c|c|c|c|c|c|}
\hline \multirow{3}{*}{ Treatments } & \multicolumn{18}{|c|}{$\%$ Total mortality } & \multirow{3}{*}{$\begin{array}{l}\text { General } \\
\text { mean }\end{array}$} \\
\hline & \multicolumn{6}{|c|}{ First generation } & \multicolumn{6}{|c|}{ Second generation } & \multicolumn{6}{|c|}{ Third generation } & \\
\hline & $\begin{array}{c}\% \\
\text { Larval }\end{array}$ & Mean & $\begin{array}{c}\% \\
\text { Prepup }\end{array}$ & $\%$ PuP & Adu & Mor.No & $\begin{array}{c}\% \\
\text { Larval }\end{array}$ & Mean & $\begin{array}{c}\% \\
\text { Prepup }\end{array}$ & $\begin{array}{c}\% \\
\text { PuP }\end{array}$ & Adu & Mor.No & $\begin{array}{c}\% \\
\text { Larval }\end{array}$ & Mean & $\begin{array}{c}\% \\
\text { Prepup }\end{array}$ & $\begin{array}{c}\% \\
\text { PuP }\end{array}$ & Adu & $\begin{array}{l}\text { Mor. } \\
\text { No }\end{array}$ & \\
\hline C. magic & 88 & $14.67 \pm 5.1$ & 10 & 0 & 2 & 0 & 95 & $15.83 \pm 7.26$ & 3 & 0 & 0 & 2 & 95 & $15.83 \pm 5.02$ & 3 & 0 & 1 & 1 & 92.6 \\
\hline C. sal & 95 & $15.83 \pm 10.7$ & 1 & 3 & 1 & 0 & 92 & $15.25 \pm 9.4$ & 5 & 2 & 1 & 0 & 94 & $15.7 \pm 6.67$ & 3 & 2 & 0 & 1 & 98.8 \\
\hline C. foliar & 89 & $14.83 \pm 6.76$ & 6 & 0 & 0 & 5 & 90 & $15.0 \pm 8.6$ & 8 & 2 & 0 & 0 & 84 & $14.0 \pm 4.2$ & 8 & 2 & 1 & 5 & 96.3 \\
\hline C. amino & 93 & $15.5 \pm 9.4$ & 6 & 0 & 1 & 0 & 83 & $13.75 \pm 4.4$ & 12 & 2 & 1 & 3 & 86 & $14.33 \pm 4.3$ & 9 & 4 & 0 & 1 & 98.2 \\
\hline Control & 33 & $5.5 \pm 3.3$ & 3 & 0 & 0 & 0 & 35 & $5.75 \pm 2.98$ & 2.5 & 1 & 0 & 0 & 25 & $4.08 \pm 3.2$ & 0 & 4 & 0 & 0 & 34.0 \\
\hline Computed $\mathrm{F}$ & \multicolumn{6}{|c|}{5.72} & \multicolumn{6}{|c|}{3.65} & \multicolumn{6}{|c|}{4.88} & \\
\hline Tabulated F & \multicolumn{6}{|c|}{2.87} & \multicolumn{6}{|c|}{2.87} & \multicolumn{6}{|c|}{2.87} & \\
\hline LSD & \multicolumn{6}{|c|}{5.45} & \multicolumn{6}{|c|}{6.47} & \multicolumn{6}{|c|}{6.59} & \\
\hline
\end{tabular}


Table 2. Biological effects of different treatments on the immature stage of $S$. littoralis for the three generation.

\begin{tabular}{|c|c|c|c|c|c|c|}
\hline \multirow{3}{*}{$\begin{array}{l}\text { Immature } \\
\text { stage }\end{array}$} & \multirow[t]{3}{*}{ Generation } & \multicolumn{5}{|c|}{ Treatments } \\
\hline & & \multicolumn{5}{|c|}{ Mean duration $\pm \mathrm{SD}$} \\
\hline & & Canda maic & Canda Sal & Canda foliar & $\begin{array}{l}\text { Canda } \\
\text { amino }\end{array}$ & Control \\
\hline \multirow{3}{*}{ Egg } & $1^{\text {st }}$ & $0,0 \pm 0.0$ & $0,0 \pm 0.0$ & $0,0 \pm 0.0$ & $0,0 \pm 0.0$ & $3.33 \pm 0.4$ \\
\hline & $2^{\text {nd }}$ & $0,0 \pm 0.0$ & $0,0 \pm 0.0$ & $0,0 \pm 0.0$ & $0,0 \pm 0.0$ & $\begin{array}{l}3.57 \pm \\
0.47\end{array}$ \\
\hline & $3^{\text {rd }}$ & $0,0 \pm 0.0$ & $0,0 \pm 0.0$ & $0,0 \pm 0.0$ & $0,0 \pm 0.0$ & $3.57 \pm 0.5$ \\
\hline \multirow{3}{*}{$\begin{array}{l}\text { Larval instars } \\
1^{\text {st }} \text { instar }\end{array}$} & $1^{\mathrm{st}}$ & $1.0 \pm 0.0$ & $1.0 \pm 0.0$ & $1.0 \pm 0.0$ & $1.0 \pm 0.0$ & $1.0 \pm 0.0$ \\
\hline & $2^{\text {nd }}$ & $1.0 \pm 0.0$ & $1.0 \pm 0.0$ & $1.25 \pm 0.0$ & $1.5 \pm 0.5$ & $1.5 \pm 0.5$ \\
\hline & $3^{\text {rd }}$ & $1.0 \pm 0.0$ & $1.0 \pm 0.0$ & $1.25 \pm 0.43$ & $1.5 \pm 0.5$ & $1.5 \pm 0.5$ \\
\hline \multirow{3}{*}{$2^{\text {nd }}$ instar } & $1^{\mathrm{st}}$ & $1.0 \pm 0.0$ & $1.0 \pm 0.0$ & $1.25 \pm 0.43$ & $1.5 \pm 0.5$ & $2.5 \pm 0.0$ \\
\hline & $2^{\text {nd }}$ & $1.25 \pm 0.43$ & $1.25 \pm 0.43$ & $1.00 \pm 0.0$ & $1.5 \pm 0.5$ & $1.25 \pm 0.43$ \\
\hline & $3^{\text {rd }}$ & $1.5 \pm 0.5$ & $1.5 \pm 0.5$ & $1.0 \pm 0.0$ & $1.5 \pm 0.5$ & $\begin{array}{l}1.25 \pm \\
0.43\end{array}$ \\
\hline \multirow[t]{3}{*}{$3^{\text {rd }}$ instar } & $1^{\text {st }}$ & $2.0 \pm 0.0$ & $1.25 \pm 0.43$ & $1.0 \pm 0.0$ & $1.5 \pm 0.5$ & $\begin{array}{l}3.25 \pm \\
0.43\end{array}$ \\
\hline & $2^{\text {nd }}$ & $1.75 \pm 0.43$ & $1.75 \pm 0.43$ & $2.25 \pm 0.43$ & $2.0 \pm 0.71$ & $2.5 \pm 0.5$ \\
\hline & $3^{\text {rd }}$ & $1.75 \pm 0.43$ & $1.75 \pm 0.43$ & $2.25 \pm 0.43$ & $1.75 \pm 0.43$ & $2.5 \pm 0.5$ \\
\hline \multirow[t]{3}{*}{$4^{\text {th }}$} & $1^{\mathrm{st}}$ & $1.75 \pm 0.43$ & $2.5 \pm 0.5$ & $2.25 \pm 0.43$ & $2.25 \pm 0.43$ & $3.0 \pm 0.0$ \\
\hline & $2^{\text {nd }}$ & $2.0 \pm 0.71$ & $2.0 \pm 0.0$ & $2.0 \pm 0.0$ & $2.5 \pm 0.5$ & $2.5 \pm 0.5$ \\
\hline & $3^{\text {rd }}$ & $2.25 \pm 0.43$ & $2.0 \pm 0.0$ & $2.75 \pm 0.43$ & $2.25 \pm 0.43$ & $2.5 \pm 0.5$ \\
\hline \multirow[t]{3}{*}{$5^{\text {th }}$} & $1^{\text {st }}$ & $2.00 \pm 0.0$ & $2.0 \pm 0.0$ & $2.75 \pm 0.43$ & $2.25 \pm 0.43$ & $3.0 \pm 0.0$ \\
\hline & $2^{\text {nd }}$ & $2.0 \pm 0.82$ & $2.0 \pm 0.0$ & $2.75 \pm 0.43$ & $2.5 \pm 0.5$ & $\begin{array}{l}2.25 \pm \\
0.43\end{array}$ \\
\hline & $3^{\text {rd }}$ & $2.5 \pm 0.5$ & $1.5 \pm 0.5$ & $2.5 \pm 0.5$ & $2.25 \pm 0.43$ & $2.5 \pm 0.5$ \\
\hline \multirow[t]{3}{*}{$6^{\text {th }}$} & $1^{\mathrm{st}}$ & $2.33 \pm 0.47$ & $2.0 \pm 0.0$ & $2.25 \pm 0.43$ & $2.75 \pm 0.43$ & $\begin{array}{l}3.75 \pm \\
0.43\end{array}$ \\
\hline & $2^{\text {nd }}$ & $2.67 \pm 0.43$ & $2.5 \pm 0.5$ & $2.00 \pm 0.0$ & $3.25 \pm 0.43$ & $2.75 \pm$ \\
\hline & $3^{\text {rd }}$ & $2.5 \pm 0.5$ & $3.0 \pm 0.0$ & $2.25 \pm 0.43$ & $2.5 \pm 0.5$ & $\begin{array}{l}2.75 \pm \\
0.43\end{array}$ \\
\hline \multirow[t]{3}{*}{ Larval duration } & $1^{\text {st }}$ & $10.08 \pm 0.5$ & $9.75 \pm 0.57$ & $10.5 \pm 0.69$ & $\begin{array}{l}11.25 \pm \\
0.59\end{array}$ & $\begin{array}{l}17.0 \pm \\
0.91\end{array}$ \\
\hline & $2^{\text {nd }}$ & $\begin{array}{l}10.67 \\
\pm 0.54\end{array}$ & $10.5 \pm 0.5$ & $\begin{array}{l}11.25 \pm \\
0.59\end{array}$ & $13.3 \pm 0.62$ & $\begin{array}{l}12.75 \pm \\
0.43\end{array}$ \\
\hline & $3^{\text {rd }}$ & $11.5 \pm 0.6$ & $10.75 \pm 0.62$ & $12.0 \pm 0.65$ & $\begin{array}{l}11.75 \pm \\
0.39\end{array}$ & $\begin{array}{l}13.0 \pm \\
0.57\end{array}$ \\
\hline $\begin{array}{l}\text { Mean } \pm \text { SD } \\
\text { larval duration }\end{array}$ & Betw.3G. & $\begin{array}{l}10.75 \pm \\
0.58\end{array}$ & $10.33 \pm 0.43$ & $\begin{array}{l}11.25 \pm \\
0.61\end{array}$ & $12.1 \pm 0.87$ & $\begin{array}{l}14.24 \pm \\
1.95\end{array}$ \\
\hline $\begin{array}{l}\text { Computed F } \\
\text { lar.duration }\end{array}$ & Betw 3G. & 4.42 & & & & \\
\hline Tabulated F & & 3.48 & & & & \\
\hline L.S.D & & 2.33 & & & & \\
\hline \multirow[t]{3}{*}{$\begin{array}{l}\text { Pre-Pupal } \\
\text { duration }\end{array}$} & $1^{\text {st }}$ & $1.0 \pm 0.0$ & $1.0 \pm 0.0$ & $1.0 \pm 0.0$ & $1.0 \pm 0.0$ & $\begin{array}{l}1.32 \pm \\
0.16\end{array}$ \\
\hline & $2^{\text {nd }}$ & $1.0 \pm 0.0$ & $1.0 \pm 0.0$ & $1.0 \pm 0.0$ & $1.0 \pm 0.0$ & $\begin{array}{l}1.25 \pm \\
0.43\end{array}$ \\
\hline & $3^{\text {rd }}$ & $1.0 \pm 0.0$ & $1.0 \pm 0.0$ & $1.0 \pm 0.0$ & $1.0 \pm 0.0$ & $1.0 \pm 0.0$ \\
\hline $\begin{array}{l}\text { Mean } \pm \text { SD } \\
\text { Pre.duration }\end{array}$ & Mean \pm SD & $1.0 \pm 0.0$ & $1.0 \pm 0.0$ & $1.0 \pm 0.0$ & $1.0 \pm 0.0$ & $\begin{array}{l}1.19 \pm \\
0.14\end{array}$ \\
\hline \multirow[t]{3}{*}{ Pupal duration } & $1^{\mathrm{st}}$ & $2.0 \pm 0.0$ & $3.0 \pm 0.0$ & $3.0 \pm 0.0$ & $3.0 \pm 0.0$ & $6.5 \pm 0.5$ \\
\hline & $2^{\text {nd }}$ & $7.0 \pm 0.0$ & $10.0 \pm 0.0$ & $0.0 \pm 0.0$ & $8.0 \pm 0.82$ & $9.25 \pm$ \\
\hline & $3^{\text {rd }}$ & $8.5 \pm 0.5$ & $9.0 \pm 0.0$ & $10.0 \pm 0.0$ & $8.5 \pm 0.5$ & $9.5 \pm 0.5$ \\
\hline $\begin{array}{l}\text { Mean } \pm \text { SD } \\
\text { pupal duration }\end{array}$ & Betw. 3 G. & $5.83 \pm 2.78$ & $7.33 \pm 3.1$ & $6.5 \pm 3.5$ & $6.6 \pm 2.48$ & $8.4 \pm 1.36$ \\
\hline $\begin{array}{l}\text { Computed F } \\
\text { for Pupal } \\
\text { duration }\end{array}$ & $\begin{array}{l}\text { Between } 3 \\
\text { G. }\end{array}$ & 0.55 & & & & \\
\hline Tabulated F & & 3.48 & & & & \\
\hline
\end{tabular}

Using nitrogen fertilizer lead to production of nitrogen- based secondary compounds such as glucosinolate. Glucosinolate compounds are the key factors being associated with the antifedant activity, Tsao, et al., (1996). In addition, Glucosinolate cramble seed extracts caused acute mortality to mosquito Aedess aegypti (L.) larvae house fly larvae Musca domestica L. and sawtoothed grain beetle, Oryzeaphyus surinamensis (L.). 


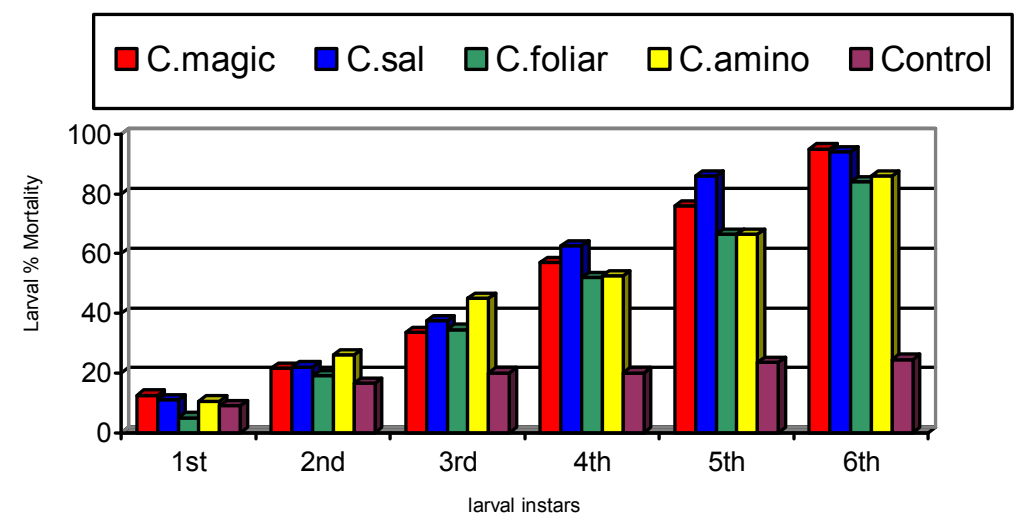

Fig. 3. A Cumulated percentage mortality within larval instars for the third generation.

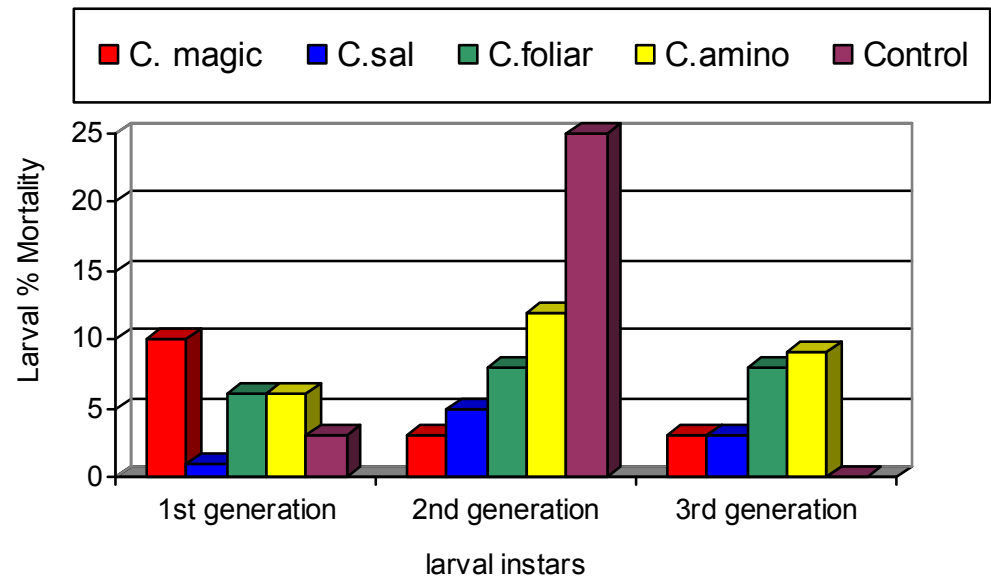

Fig. 4. Percentage mortality of pre-pupae before pupation of S. littoralis within different treatments for the three generation

\section{Percentage of pupation:}

Data in Table (3) indicated that, the least mean pupation percent were resulted in three generations, when larvae fed upon cotton leaves were sprayed with four compounds of foliar fertilizers, where the mean pupation percent were $(2.0 \pm$ $0.0,3.33 \pm 0.47,4.0 \pm 2.16$ and $5.0 \pm 2.45$ ) obtained from larvae fed on leaves were sprayed with Canada magic, Canada sal, Canada amino and Canada foliar respectively. However, the highest mean percentage pupation obtained from larvae fed on leaves sprayed with fresh water (control), where the mean percentage pupation were $68.0 \pm 5.3$. Analysis of variance showed that differences in percentage pupation between treatments and control were highly significant (L.S.D=6.3). Generally, the obtained results showed that, the pupation was severely affected by the four treatments of foliar fertilizers. Also, these results in control treatment were in harmony with that of El-Saadany et al., (1994), where, larvae fed on cotton leaves as host plant gave the same percentage of pupation in both generations. 
Table 3. Biological effects of different treatments on $S$. littoralis for the three generations.

\begin{tabular}{|c|c|c|c|c|c|c|}
\hline \multirow{2}{*}{$\begin{array}{c}\text { Percentage } \\
\text { stage }\end{array}$} & \multirow[t]{2}{*}{ Generations } & \multicolumn{5}{|c|}{ Treatments } \\
\hline & & $\begin{array}{l}\text { Canda } \\
\text { magic }\end{array}$ & Canda sal & Canda foliar & $\begin{array}{l}\text { Canda } \\
\text { amino }\end{array}$ & Control \\
\hline \multirow{3}{*}{ Pupation \% } & $1^{\text {st }}$ & 2.0 & 4.0 & 5.0 & 1.0 & 67.0 \\
\hline & $2^{\text {nd }}$ & 2.0 & 3.0 & 2.0 & 6.0 & 62.0 \\
\hline & $3^{\text {rd }}$ & 2.0 & 3.0 & 8.0 & 5.0 & 75.0 \\
\hline Mean \pm SD & & $2.0 \pm 0.0$ & $3.33 \pm 0.47$ & $5.0 \pm 2.45$ & $4.0 \pm 2.16$ & $68.0 \pm 5.3$ \\
\hline \multirow{3}{*}{$\begin{array}{c}\text { Adult } \\
\text { emergence }\end{array}$} & $1^{\text {st }}$ & 0.0 & 0.0 & 5.0 & 0.0 & 64.0 \\
\hline & $2^{\text {nd }}$ & 2.0 & 0.0 & 0.0 & 3.0 & 57.0 \\
\hline & $3^{\text {rd }}$ & 1.0 & 1.0 & 5.0 & 1.0 & 72.0 \\
\hline Mean \pm SD & & $1.0 \pm 0.82$ & $0.33 \pm 0.47$ & $3.33 \pm 2.36$ & $1.33 \pm 1.24$ & $64.3 \pm 6.1$ \\
\hline \multirow{3}{*}{$\begin{array}{c}\text { Adult } \\
\text { deformatiom }\end{array}$} & $1^{\text {st }}$ & 2.0 & 1.0 & 0.0 & 1.0 & 0.0 \\
\hline & $2^{\text {nd }}$ & 0.0 & 1.0 & 0.0 & 1.0 & 0.0 \\
\hline & $3^{\text {rd }}$ & 1.0 & 0.0 & 1.0 & 0.0 & 0.0 \\
\hline Mean \pm SD & & $1.0 \pm 0.82$ & $0.66 \pm 0.47$ & $0.33 \pm 0.47$ & $0.66 \pm 0.47$ & $0.0 \pm 0.0$ \\
\hline \multirow{3}{*}{$\begin{array}{l}\text { No. of egg per } \\
\text { female }\end{array}$} & $1^{\text {st }}$ & 0.0 & 0.0 & 0.0 & 0.0 & 2014 \\
\hline & $2^{\text {nd }}$ & 0.0 & 0.0 & 0.0 & 0.0 & 1922 \\
\hline & $3^{\text {rd }}$ & 0.0 & 0.0 & 0.0 & 0.0 & 2011 \\
\hline Mean \pm SD & & 0.0 & 0.0 & 0.0 & 0.0 & $1982.3 \pm 42.7$ \\
\hline \multirow{3}{*}{ Hatchability } & $1^{\text {st }}$ & 0.0 & 0.0 & 0.0 & 0.0 & 85 \\
\hline & $2^{\text {nd }}$ & 0.0 & 0.0 & 0.0 & 0.0 & 99 \\
\hline & $3^{\text {rd }}$ & 0.0 & 0.0 & 0.0 & 0.0 & 99 \\
\hline Mean $\pm S D$ & & 0.0 & 0.0 & 0.0 & 0.0 & $94.33 \pm 6.6$ \\
\hline
\end{tabular}

Computed $(F)$ between $\%$ pupation $=21.01$

Tabulated $(F)=3.48$

L.S.D $=6.3$

\section{Percentage of adult emergence:}

Data in Table (3), also indicated that, all larvae fed on treated leaves gave the least percentage of adults emergence in the three generations, where the mean percentage were $(0.33 \pm 0.47,1.0 \pm 0.82,1.33 \pm 1.24$ and $3.33 \pm 2.36)$, when larvae fed on leaves were sprayed with Canada sal, Canada magic, Canada amino and Canada foliar respectively. While, larvae fed on untreated leaves (Control) gave the highest mean percentage of adult emergence $(64.3 \pm 6.1)$. The same trend was observed by 
El-Saadany et al., (1994), where larvae fed on cotton leaves, gave the same percentage of adult emergence in both generations.

\section{Adult malformation:}

The results indicated that untreated did not show any malformation effects, while the four compounds of foliar fertilizers caused a few malformations. Malformed moths failed to shed pupation. Some moths appeared with shortened wings, while others failed to expand their wings. Moths displaying any of these malformation died soon after emergence.

\section{Number of eggs per females and hatchability:}

Data in Table (3) showed that, no eggs were laid by resulting females for the four treatments as foliar fertilizers in the three generations. However, the number of eggs was laid for the untreated (Control) ranged from (1922-2014) eggs / female in the three generations. Also, the percentage of egg hatchability ranged from (85-99 $\%$ ) for the untreated (control) in the three generations. These results were nearly observed by El-Saadany et al., (1994), when larvae fed on cotton leaves as host plant gave the same number of eggs per female and the same percentage of hatchability in both generations.

\section{Larval weight (g.):}

Data in Table (4) revealed that, the mean weight of remaining full grown larvae $\left(6^{\text {th }}\right.$ instar $)$ was $(0.20 \pm 0.03 \mathrm{~g}$./ larvae) recorded for larvae fed on cotton leaves were sprayed with Canda foliar followed by $(0.21 \pm 0.02,0.18 \pm 0.09$ and 0.17 \pm 0.08 g.) / larva recorded for Canada magic, Canada amino and Canada sal, respectively, in comparison with $(0.19 \pm 0.02 \mathrm{~g}$. $)$ / larvae of untreated leaves, during the study periods of three generations. So, these data demonstrated that the larval weight recorded insignificant differences between treated and untreated. These results disagree with those of Greiss and Petkov (2001), and Sannappa et al., (2003) they reported that the fertilization of mulberry tree with different methods more effective on Silkworm, Bombyx mori larval body weight than control and it is important for biological aspects. However, Soldaat and Vrieling (1992) reported that larval weight of Tyria jacobaeae positively correlated with nitrogen concentration of food plant.

\section{Pupal weight (g.):}

From the results obtained in Table (4), the mean weight of all the four treatments may be arranged in an ascending order with respect to pupal weights as follows (0.22 $\pm 0.03,0.19 \pm 0.02,0.19 \pm 0.09$ and $0.16 \pm 0.02 \mathrm{~g}$.$) / Pupa recorded$ with Canada foliar, Canada magic, Canada amino and Canada sal, respectively, compared to the control, where the mean pupal weight was $0.20 \pm 0.03 \mathrm{~g}$. / pupa. 
These results agreed with Saad and Nabil (2012), they were noticed no significant difference for all treatments. These results disagreed with Wheeler et al., (1998) who reported that male and female Spodoptera pectinicornis pupal biomass were significantly greater when larvae were fed leaves from high nitrogen fertilized plant. In the same trend Bansode and Purohit (2013) reported that the pupal weight of diamondback moth Plutella xylostella were also significantly affected by nitrogen levels.

Table 4. Larval weight and pupal weight of $S$. littoralis survived, when larval instars fed on cotton leaves treated with four foliar fertilizers among three generations.

\begin{tabular}{|c|c|c|c|c|c|c|c|c|}
\hline \multirow[t]{3}{*}{ Treatments } & \multicolumn{3}{|c|}{ Larval weight } & \multirow{3}{*}{$\begin{array}{l}\text { Mean } \pm \text { SD } \\
\text { Bet. } 3 \text { G. }\end{array}$} & \multicolumn{3}{|c|}{ Pupal weight } & \multirow{3}{*}{$\begin{array}{l}\text { Mean } \pm \text { SD } \\
\text { Bet. } 3 \mathrm{G} .\end{array}$} \\
\hline & \multicolumn{3}{|c|}{ Mean $\pm \mathrm{SD}$} & & \multicolumn{3}{|c|}{ Mean \pm SD } & \\
\hline & $1^{\mathrm{st}} \mathrm{G}$. & $2^{\text {nd }} \mathrm{G}$. & $3^{\text {rd }} \mathrm{G}$. & & $1^{\mathrm{st}} \mathrm{G}$. & $2^{\text {nd }} \mathrm{G}$. & $3^{\text {rd }} \mathrm{G}$. & \\
\hline C.magic & $0.15 \pm 0.05$ & $0.18 \pm 0.01$ & $0.21 \pm 0.02$ & $0.21 \pm 0.02$ & $0.18 \pm 0.0$ & $0.17 \pm 0.02$ & $0.22 \pm 0.05$ & $0.19 \pm 0.02$ \\
\hline C.sal & $0.18 \pm 0.0$ & $0.16 \pm 0.02$ & $0.17 \pm 0.08$ & $0.17 \pm 0.08$ & $0.16 \pm 0.0$ & $0.14 \pm 0.01$ & $0.18 \pm 0.0$ & $0.16 \pm 0.02$ \\
\hline C. foliar & $0.15 \pm 0.02$ & $0.23 \pm 0.04$ & $0.21 \pm 0.05$ & $0.20 \pm 0.03$ & $0.18 \pm 0.02$ & $0.24 \pm 0.07$ & $0.23 \pm 0.04$ & $0.22 \pm 0.03$ \\
\hline C. amino & $0.17 \pm 0.01$ & $0.17 \pm 0.01$ & $0.19 \pm 0.04$ & $0.18 \pm 0.09$ & $0.18 \pm 0.01$ & $0.18 \pm 0.03$ & $0.20 \pm 0.05$ & $0.19 \pm 0.09$ \\
\hline Control & $0.15 \pm 0.05$ & $0.21 \pm 0.0$ & $0.20 \pm 0.03$ & $0.19 \pm 0.03$ & $0.15 \pm 0.0$ & $0.21 \pm 0.06$ & $0.22 \pm 0.07$ & $0.20 \pm 0.03$ \\
\hline Computed & \multicolumn{4}{|c|}{0.35} & \multicolumn{4}{|c|}{1.6} \\
\hline Tabulated & \multirow{3}{*}{\multicolumn{4}{|c|}{3.48}} & \multirow{3}{*}{\multicolumn{4}{|c|}{3.48}} \\
\hline (F)at level & & & & & & & & \\
\hline $5 \%$ & & & & & & & & \\
\hline
\end{tabular}




\section{REFERENCES}

1. Amin, A. A, Gergis, M. F. 2006. Integrated management strategies for control of cotton key pests in middle Egypt. Agron. Res. 4, 121-128.

2. Badr, N. A. 1967. Effect of different host plants on the development and reproduction of the cotton leafworm, Prodemia litura F. M.Sc. Thesis, Alexandria Univ.

3. Bahram Naseri, Yagoub Fathipour, Saeid Moharramipour and Vahid Hosseininaveh. 2009. Comparative life history and fecundity of Helicoverpa armigera (Humber) (Lepidoptera : Noctudidae) on different soybean varieties. Entomol. Sci. 12, 147-154.

4. Bansode, G. M. and Purohit, M. s. 2003. Effect of defferent level of Nitrogenous fertilizers on level and post larval development of Plutella xylostella (L.N.N.) infesting cauliflower. The Bioscan 8 (2): 545-548.

5. Bryant JP, FS, Chapin, DR Klein. 1983. Carbon / nutrient balance of boreal plants in relation to vertebrate herbivory. Oikos 40: 357- 368.

6. Carnevalli, P. C., Adde, M. F. V. and Calafior, M. H. (1990): Effect of nitrogen in maize on Spodoptera frugiperda. Ecossistema 18: 108-118.

7. El-Naggar, A. Z. (2009): Efficacy of some foliar fertilizers and alternative chemicals on the spiny bollworm, Erias insulana (Boisd.) Larvae (Lepidoptera : Noctudidae) and their side effect on protease activity. J. Entomol. 9 (6): 375381.

8. El-Naggar, A. Z. and M. E., Tawfeek. 2012. Efficacy of some foliar fertilizers and alternative chemicals on the spiny bollworm, Earias insulana (Boisd.) larvae (Lepidoptera : Noctuidae) and their side effect on protease activity. J. Entomol. 9 (6) : 375 - 381.

9. El-Saadany, G. B., Hamed, A.a., Zidan, Z. H., Aziza M. Sharaby and Shadia Abdel-Aziz. 1994. Biotic potential of the cotton leafworm, Spodoptera littoralis (Boisd.). (Lepidoptera : Noctudidae) on five host plants. $5^{\text {th }}$ comf. Agric. Dev. Res. Fac. Agric. Ain Shams univ. Cairo, Egypt 2: 927-944.

10. Greiss, H. and Petkov, N. 2001. Effect of balanced NPK and micronutrient fertilization of mulberry plantations on the development and productivity of silkworm (Bomyx mori L) BJAS Arch., 7 (1): 81-85.

11. Hwang, Shaw- Yhi, Cheng- Hsiang liu and Tse-Chishen. 2008. Effects of plant nutrient availability and host plant species on the performance of two pieris butterflies (Lepidoptera: Pieridae). Biochem System. and Ecol . 36. Issue 7 pp 505-513.

12. Mesbah, H. A., M. M., Ibrahim, E. H., Tayeb, A. Z., El-Naggar and H. M., ElNimr. 2000. Plant health anew approach for the attainment of tolerant plants 
to pests infestation: Effect of fertilization and application of nutritive elements on the infestation of cotton with bollworm Adv. Agric. Res. 5: 1437- 14454.

13. Meyer, G. A. 2000. Interactive effects of soil fertility and herbivory on Brassica. nigra oikes 22 : 433-441.

14. Moufied, A. Mousa, Zaher, M. A. and Kotby, Fawkia. 1960. Abundance of the cotton leafworm in relation to host plants. Bull. Soc. Ent. Egypt, xLiv pp 240251.

15. Ramesh, P., M., Singh and A., Subba Rao. 2005. Organic farming: Its relevance to the effects of organic fertilizers on insect pest and diseases of rice. Indian context. Current Scientist, 88, no 4: 561-568.

16. Rong Tsao, Mark Reuber, Larvy Johnson and Jod R. Coats. 1996. Insecticidal toxicites of Glucosinolate containing extracts from cramble seeds. J. Agric. Entomolo. 13 (12) : 109-120.

17. Saad, M. S. I. and Nabil, H. A. 2012. Effects of some foliar fertilizations on some biological aspects of mulberry silkworm, Bombyx mori L. Egypt J. Agric. Res., 90 (2) 547-558.

18. Sannappa, B., Devaiah, M. C., Govindan, R and Doreswamy, C. 2003. Impact of feeding mulberry, raised with varied nitrogen levels under rainfed conditions, through different feeding methods on rearing performance of NB4 D2 race of silkworm, Bombyx mori L. Advan Plant Sci., 16 (2) : 619-623.

19. Setamous, M., Schulthess, F., Bosque- Perez, N. K. and Odjo- Thomas, A. 1993. Effect of plant nitrogen and silica on the bionomics of Sesamia calamistis. Bull. Entomol. Res. 83 (3): 405-411.

20. Soldaat, L. L. and Vrieling, K. 1992. The influence of nutritional and genetic factors on larval Entomol - Exp. App. 62 (1) : 29-36.

21. Wheeler, G. S, Van, Y.K. and Center, T. D. 1998. Fecundity and egg distribution of herbivore Spododoptera pectinicornis as influenced by quality of the floating aquatic plant pistia statiots. Entomol. Exp. App. 86 (3) : 295304.

22. Xia, j., ma-yan., wang-chunyi., Xia, u. Y., and Wang, c. y. 1997. Effects of various rates of nitrogen fertilizer in different host plants an development and fecundity of the cotton bollworm, Helicoverpa armigera. Acta Ent- Sinca 40: $95-102$

23. Ying-Zhi chen, Lili, Chil- Wei Wang, Chin-Chang Yeh and Shaw-Yhi Hwang. 2004. Response of two pieris (Lepidoptera : Pieridae) Species to fertilization of host plant. Zoological studies 43 (4) : 778- 786. 


\section{التأثيرات الجانبية لبعض الأسمدة الورقية على الصفات البيولوجية لاودة ورق القطن تحت ظروف المعمل}

عبد المسيح وهبة مقار ، عريان شحاته منصور ، امل عبد الحليم عبد الله

$$
\text { معهد بحوث وقاية النباتات - مركز البحوث الزراعية - الدقى - جيزة }
$$

أجريت هذة الدر اسة في محطة البحوث الزر اعية بقها محافظة القليوبية خلال موسم زر اعة

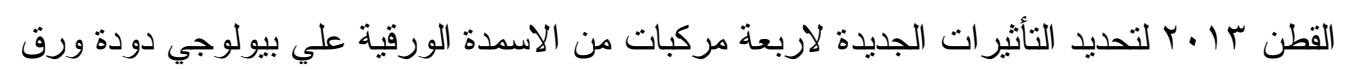

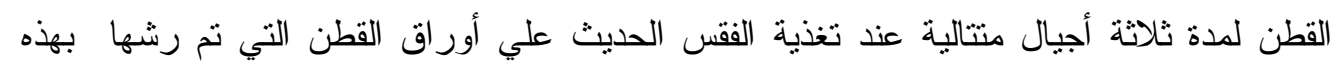

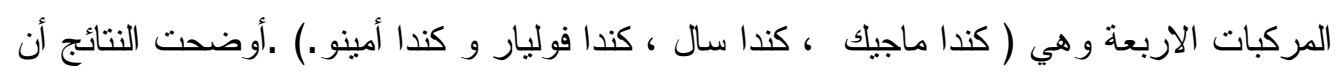

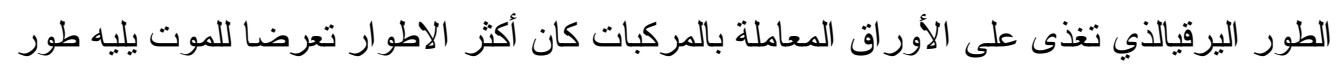

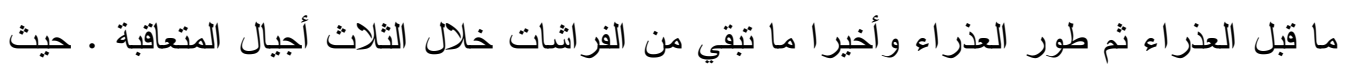


و 96.3\% ) في كل من كندا سال ، كندا أمينو، وكندا ماجيك ثم كندا فوليار علي التو الي.

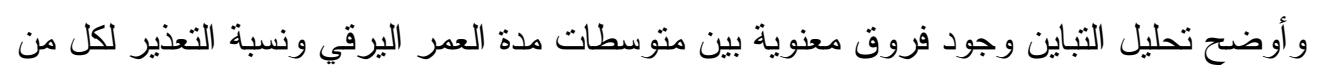

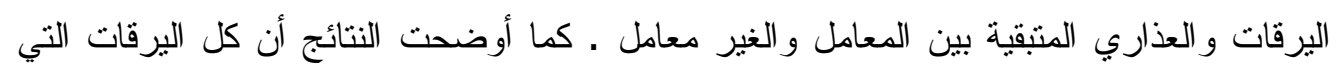

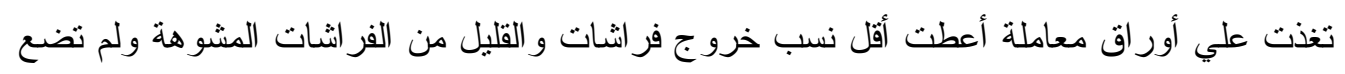

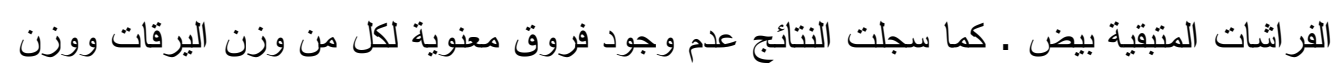
العذاري بين التي تغذت علي أور اق معاملة و الغير معاملة خلال الثلاث أجيال. 